\title{
Morphological and Biochemical Characterization of Endophytic Bacteria from Leaves of Tamarind (Tamarindus indica)
}

\author{
Alka Sawarkar1, 2*, R.K. Sharma ${ }^{1}$, Vidhi Gautam ${ }^{1}$, Madhu Swamy ${ }^{3}$, Anju Nayak ${ }^{4}$ and Kabita Roy ${ }^{5}$ \\ ${ }^{1}$ Department of Veterinary Pharmacology and Toxicology, College of Veterinary Science and Animal Husbandry, NDVSU, \\ Jabalpur (M.P), INDIA \\ ${ }^{2}$ Department of Veterinary Pharmacology and Toxicology, Nagpur Veterinary College, MAFSU, Nagpur, (Maharashtra), INDIA \\ ${ }^{3}$ Department of Veterinary Pathology, College of Veterinary Science and Animal Husbandry, NDVSU, Jabalpur (M.P), INDIA \\ ${ }^{4}$ Department of Veterinary Microbiology, College of Veterinary Science and Animal Husbandry, NDVSU, Jabalpur (M.P), INDIA \\ ${ }^{5}$ Department of Veterinary Medicine, College of Veterinary Science and Animal Husbandry, NDVSU, Jabalpur (M.P), INDIA \\ "Corresponding author: A Sawarkar; E-mail: alkasawarkar@gmail.com
}

Received: 27 Nov., 2020

Revised: 02 Feb., 2021

Accepted: 10 Feb., 2021

\begin{abstract}
Endophytes are ubiquitous organisms that live within the host plants without causing any apparent symptom of disease. The aim of the study was to identify the various morphological characteristics of endophytic bacteria from leaves of Tamarindus indica. The preliminary identification of the endophytic bacterial isolates was done based on various morphological features of isolated endophytic bacteria from leaves of Tamarindus indica. Growth characteristics of endophytic bacteria isolated from Tamarindus indica on King's B media showed that colonies were either irregular or circular in shape, either flat elevation on petri plate or of raised elevation, margin of colonies were either undulated or entire, the surface of the growth opaque and white in colour. All the endophytic bacterial isolates from leaves of Tamarindus indica were non-haemolytic in nature. Growth characteristic of isolated endophytic bacteria from Tamarindus indica in BHI broth showed turbidity and pellicle formation, either they form sediment or ring. The microscopic examination of endophytic bacterial isolates had shown that all endophytic bacterial isolates from Tamarindus indica were gram positive rods. Isolated endophytic bacteria were tested for various biochemical tests also. Based on the findings the endophytic bacteria were characterized and providing insights on the nature of microbiome present in the leaves of Tamarind (Tamarindus indica).
\end{abstract}

\section{HIGHLIGHTS}

(0 The colony characteristics of endophytic bacteria isolated from leaves of Tamarindus indica were circular in shape with wavy mucoid and soft irregular margin.

(0 The colonies were entire, the surface of the growth was smooth, opaque and white in colour.

Keywords: Endophytic bacteria, Tamarindus indica, morphological characterization

Antimicrobial resistance is one of the major public health problems especially in developing countries like India where relatively easy availability and inappropriate use of antibiotics leads to higher incidence of resistance. Research on antibiotics and other microbial natural products is pivotal in the global fight against the growing problem of antibiotic resistance. It is necessary to find new antibiotics to tackle this problem (Compant et al., 2010; Beneduzi et al., 2013). Global health problems due to drug resistance among pathogenic microorganisms have necessitates the urgent need for new and effective antimicrobial agents. Tamarindus indica Linn is one of the most widespread trees of the Indian subcontinent. Several authors have

How to cite this article: Sawarkar, A., Sharma, R.K., Gautam, V., Swamy, M., Nayak, A. and Roy, K. (2021). Morphological and biochemical characterization of endophytic bacteria from leaves of tamarind (Tamarindus indica). J. Anim. Res., 11(2): 317-323. Source of Support: None; Conflict of Interest: None क्ष 
proposed various geographical areas as the origin of the tamarind tree. Tamarind fruit was at first thought to be produced by an Indian palm, as the name tamarind comes from a Persian word 'tamar-i-hind', meaning 'date of India'. Its name 'amlika' in Sanskrit indicates its ancient presence in the country (Mishra, 1997). It is a large evergreen tree with an exceptionally beautiful spreading crown, and is cultivated throughout the world except in the Himalayas and western dry regions (Rao et al., 1999). In the present study, endophytic bacteria were isolated from the leaves of Tamarindus indica and their morphological characterization was done.

\section{MATERIAL AND METHODS}

\section{Location and place of work}

The proposed work was conducted in the Department of Veterinary Pharmacology and Toxicology, College of Veterinary Science and Animal Husbandry, N.D.V.S.U., Jabalpur (M.P.).

\section{Collection of leaves}

Fresh mature leaves of of Tamarindus indica were procured from, three different places of Jabalpur viz. Jawaharlal Nehru Krishi Viswa Vidyalaya (J.N.K.V.V), Tropical Forest Research (T.F.R.I.), State Forest Research Institute (S.F.R.I), Jabalpur. Samples were immediately brought to laboratory and were used within $24 \mathrm{hrs}$ and finally processed for isolation of endophytic bacteria.

\section{Sterilization of leaves}

The sterilization of leaves and isolation of endophytic bacteria from the leaves was done according to Mahajan et al. (2014), with some modifications. The leaves were excised with autoclaved scalpel and forceps in laminar air flow.

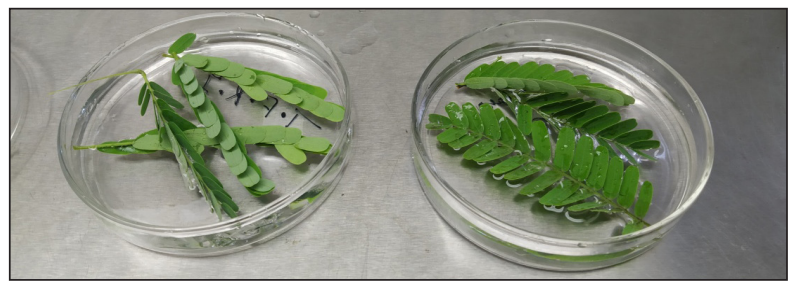

Fig. 1: Sterilization of leaves and isolation of endophytic bacteria from Tamarindus indica

\section{Sterility check}

To confirm that the surface of leaves were effectively sterilized, $1 \mathrm{ml}$ of the sterile distilled water that was used in final rinse of surface sterilization procedures was placed on to nutrient agar media and incubated at $37^{\circ} \mathrm{C}$ for 24 hrs. Then bacterial growths were observed.

\section{Preparation and sterilization of media}

King's B (KB) media (HiMedia), Mueller Hinton media (HiMedia), Blood agar media (HiMedia) and BHI broth (HiMedia) were prepared by adding agar into the distilled water. Hot plate was used for the proper mixing of media and autoclaved at $121^{\circ} \mathrm{C}$ for $15-20$ minutes at $15 \mathrm{lbs}$.

\section{Inoculation of leaves and isolation of endophytic bacteria}

The media were poured into different autoclaved small petri plates and leaves of the plant were embedded in small petri plates. These plates were then incubated at $37^{\circ}$ $\mathrm{C}$ for $24 \mathrm{hrs}$. Characterization of the bacteria was done according to its morphology and by Gram's staining. After that a single colony was transferred into BHI broth and incubated at $37^{\circ} \mathrm{C}$ for 24 hours.

\section{Morphological characterization}

Form, elevation, margin, surface, opacity and chromogenesis of isolated endophytic bacterial colonies were noted.

Growth characteristics of endophytic bacteria isolated from Tamarindus indica on King's B media showed that 66.67 per cent of isolates were irregular in shape while 33.33 per cent were circular in shape, 73.33 percent showed flat elevation on petri plate while 26.67 per cent were of raised elevation, margin of 73.33 per cent colonies were undulated while 26.67 per cent showed entire, the surface of the growth was smooth for the undulated colonies and 86.67 per cent growth were opaque and white in colour.

\section{Purification of endophytic bacteria}

For purification of endophytic bacteria, sub culturing was mainly done by streaking a loop full of BHI broth on the fresh pre solidified blood agar plates and then incubated 


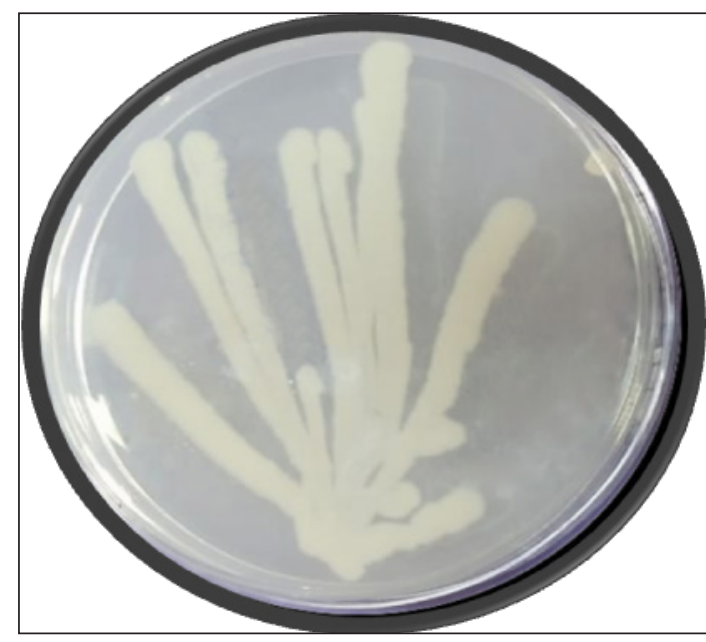

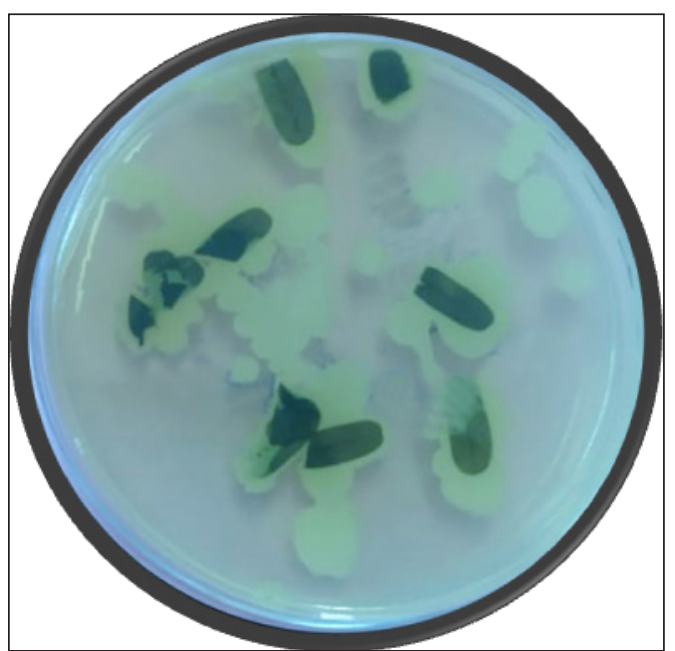

Fig. 2: Growth of Endophytic bacteria from leaves of Tamarindus indica on King's B Media

at $37^{\circ} \mathrm{C}$ for $24 \mathrm{hrs}$. After incubation the colony was transferred into BHI broth and then incubated at $37^{\circ} \mathrm{C}$ for $24 \mathrm{hrs}$ and purity was checked by Gram's staining and stored for further work.

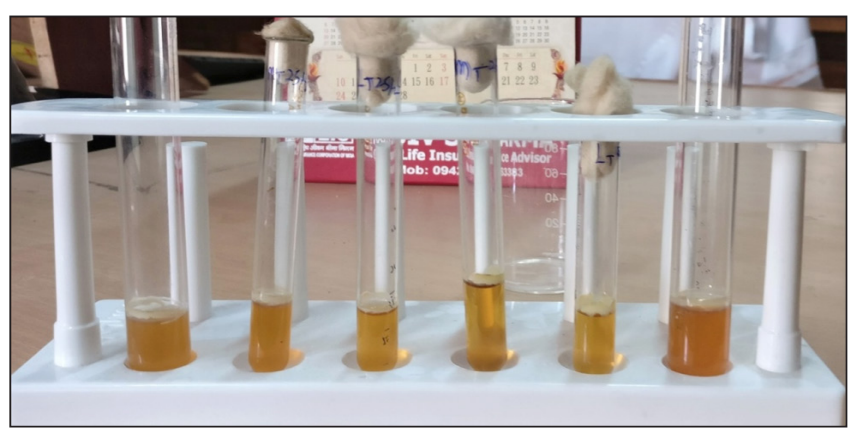

Fig. 3: Growth of Endophytic bacteria from leaves of Tamarindus indica in BHI broth

Growth characteristic of isolated endophytic bacteria from Tamarindus indica in BHI broth showed characteristics as 33.33 per cent isolates with turbidity and 80 per cent isolates with pellicle formation. Sediment formation was seen in 26.67 per cent isolates and 53.33 per cent isolate showed ring formation.

Growth of Endophytic bacteria from leaves of Tamarindus indica on 5 per cent sheepblood agar

Colonies of endophytic bacteria grown on King's B agar were transferred to 5 per cent sheep blood agar plates and incubated at $37^{\circ} \mathrm{C}$ for $24 \mathrm{hrs}$. All the isolates from Tamarindus indica were non-haemolytic in nature.

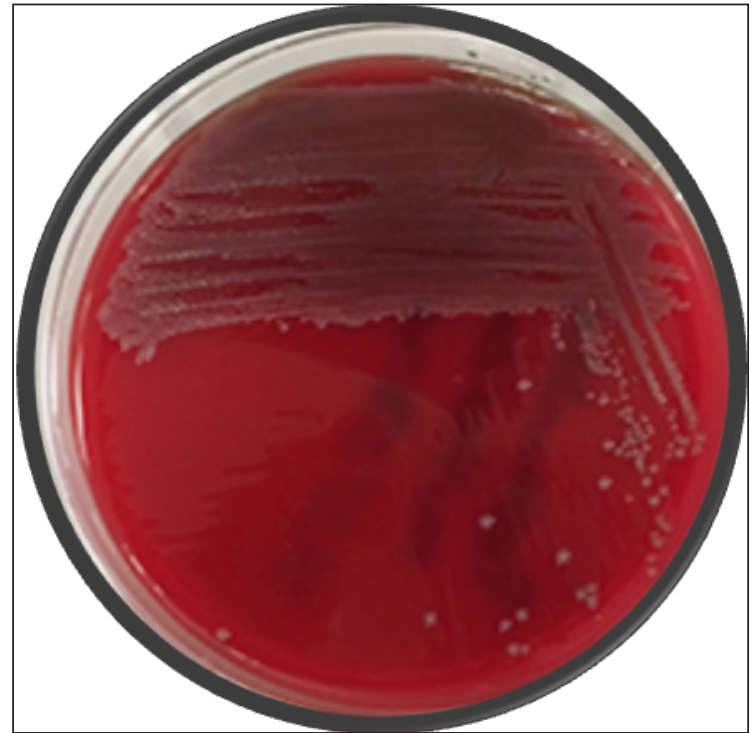

Fig. 4: Growth of Endophytic bacteria from leaves of Tamarindus indica on 5 per cent Sheep blood agar

\section{Gram's Staining}

The smear was prepared and fixed. Gently flooded the smear with Gram's iodine and allowed to stand for 1 minute. Tilted the slide gently and rinsed with distilled water. Decolorized with 95 percent ethyl alcohol and tilted 
Table 1: Growth of Endophytic bacteria from leaves of Tamarindus indica on King's B media

\begin{tabular}{|c|c|c|c|c|c|c|c|}
\hline Sl. No. & Isolate No. & Form & Elevation & Margin & Surface & Opacity & Chromo-genesis \\
\hline 1 & $\mathrm{JN}-1 \mathrm{a}$ & Irregular & Flat & Undulated & Smooth & Opaque & Absent \\
\hline 2 & $J N-1 b$ & Irregular & Flat & Undulated & Smooth & Opaque & Absent \\
\hline 3 & $\mathrm{JN}-1 \mathrm{c}$ & Circular & Flat & Undulated & Smooth & Opaque & Absent \\
\hline 4 & $\mathrm{JN}-1 \mathrm{~d}$ & Irregular & Raised & Entire & Smooth & Opaque & Absent \\
\hline 5 & $\mathrm{JN}-1 \mathrm{e}$ & Irregular & Flat & Undulated & Smooth & Glistening & Absent \\
\hline 6 & $\mathrm{TF}-2 \mathrm{a}$ & Irregular & Flat & Undulated & Smooth & Opaque & Absent \\
\hline 7 & $\mathrm{TF} 2 \mathrm{~b}$ & Circular & Raised & Entire & Smooth & Opaque & Absent \\
\hline 8 & TF-2c & Irregular & Flat & Undulated & Smooth & Opaque & Absent \\
\hline 9 & $\mathrm{TF}-2 \mathrm{~d}$ & Irregular & Flat & Undulated & Smooth & Opaque & Absent \\
\hline 10 & TF-2e & Circular & Flat & Entire & Smooth & Opaque & Absent \\
\hline 11 & SF-3a & Irregular & Raised & Undulated & Smooth & Opaque & Absent \\
\hline 12 & SF-3b & Circular & Flat & Undulated & Smooth & Opaque & Absent \\
\hline 13 & SF-3c & Irregular & Flat & Undulated & Smooth & Opaque & Absent \\
\hline 14 & SF-3d & Circular & Raised & Entire & Smooth & Glistening & Absent \\
\hline 15 & SF-3e & Irregular & Flat & Undulated & Smooth & Opaque & Absent \\
\hline
\end{tabular}

JN- Jawaharlal Nehru Krishi Viswa Vidyalaya (J.N.K.V.V), TF- Tropical Forest Research (T.F.R.I.), SF-State Forest Research Institute (S.F.R.I), Jabalpur.

Table 2: Growth of endophytic bacteria isolated from leaves of Tamarindus indica in BHI broth

\begin{tabular}{|c|c|c|c|c|c|}
\hline Sl. No. & Isolate No. & Turbidity & Pellicle & Sediment & Ring formation \\
\hline 1 & $\mathrm{JN}-1 \mathrm{a}$ & Absent & Present & Absent & Present \\
\hline 2 & $\mathrm{JN}-1 \mathrm{~b}$ & Absent & Present & Absent & Absent \\
\hline 3 & $\mathrm{JN}-1 \mathrm{c}$ & Present & Present & Present & Absent \\
\hline 4 & JN-1d & Absent & Present & Absent & Present \\
\hline 5 & $\mathrm{JN}-1 \mathrm{e}$ & Absent & Present & Absent & Present \\
\hline 6 & $\mathrm{TF}-2 \mathrm{a}$ & Present & Present & Absent & Present \\
\hline 7 & $\mathrm{TF}-2 \mathrm{~b}$ & Absent & Absent & Present & Present \\
\hline 8 & $\mathrm{TF}-2 \mathrm{c}$ & Absent & Present & Absent & Absent \\
\hline 9 & $\mathrm{TF}-2 \mathrm{~d}$ & Absent & Absent & Absent & Absent \\
\hline 10 & $\mathrm{TF}-2 \mathrm{e}$ & Present & Present & Absent & Present \\
\hline 11 & SF-3a & Absent & Present & Absent & Present \\
\hline 12 & SF-3b & Present & Absent & Present & Absent \\
\hline 13 & SF-3c & Present & Present & Absent & Present \\
\hline 14 & SF-3d & Absent & Present & Absent & Absent \\
\hline 15 & SF-3e & Absent & Present & Present & Absent \\
\hline
\end{tabular}

the slide gently and applied alcohol drop by drop to 10 seconds. Immediately rinsed with distilled water gently flooded with safranin to counter stain and allowed to stand for 1 minute. Tilted the slide gently and rinsed with distilled water, dried the slide. Viewed the smear under 100X microscope.

\section{Gram's staining of Endophytic bacterial isolated from leaves Tamarindus indica}

Endophytic bacteria isolated from leaves of Tamarindus indica from Jawaharlal Nehru Krishi Viswa Vidyalaya JN(J.N.K.V.V), Tropical Forest Research TF-(T.F.R.I.), State Forest Research Institute SF-(S.F.R.I) Jabalpur, showed gram positive reaction and were found to be rods.

\section{Biochemical characterization}

The endophytic bacteria isolated from Tamarindus indica had shown positive reaction to Catalase test, Coagulase test, Voges-Proskauer (VP), orthonitrophenyl $\beta$-galactoside (ONPG), Urease, Arginine utilization and 
Sugar fermentation tests were done. Jawaharlal Nehru Krishi Viswa Vidyalaya JN- (J.N.K.V.V), Tropical Forest Research TF-(T.F.R.I.), State Forest Research Institute SF- (S.F.R.I) Jabalpur.

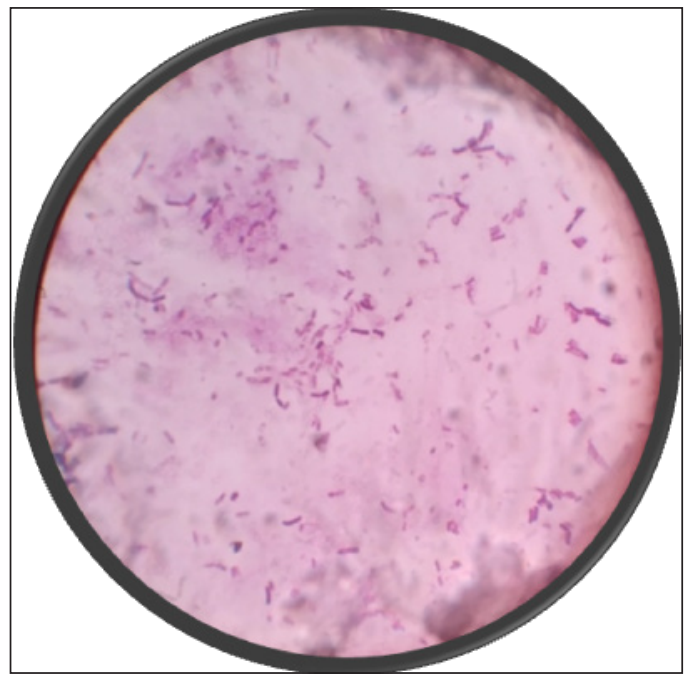

Fig. 5: Gram's staining of Endophytic bacterial isolated from leaves Tamarindus indica

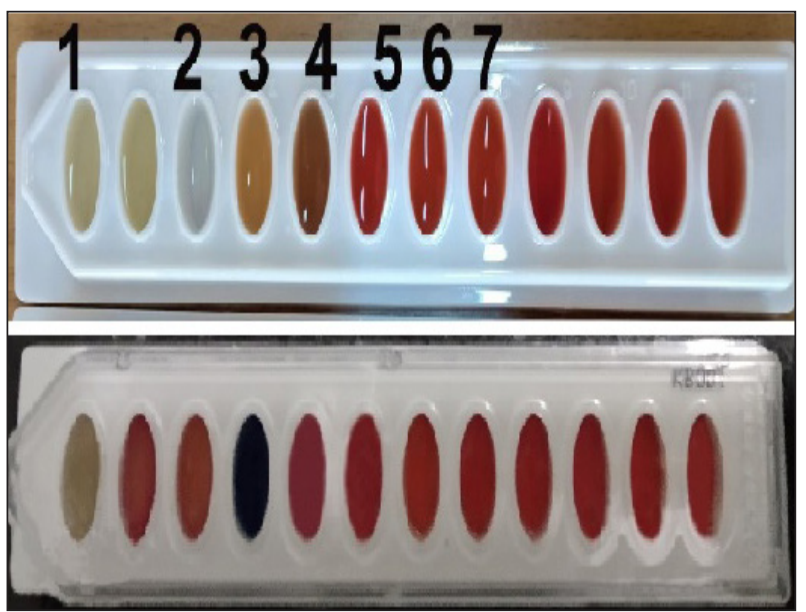

Fig. 6: VP (1), ONPG (2), Urease (3), Arginine utilization (4) and Sugar fermentation tests $(5,6,7)$ of Endophy bacteria isolated from leave Tamarindus indica

The endophytic bacteria isolated from Tamarindus indica had shown positive reaction to catalase, Vogasproskaur's (VP) Orthro-Nitrophenyl- $\beta$-galactoside (ONPG), urease and negative reaction to coagulase, arginine utilization test.

Journal of Animal Research: v. 11, n. 2, April 2021

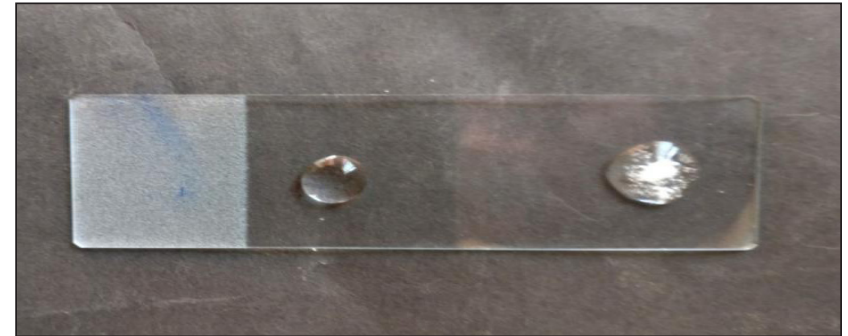

Fig. 7: Coagulase test reaction of isolated Endophytic bacteria from leaves of Tamarindus indica

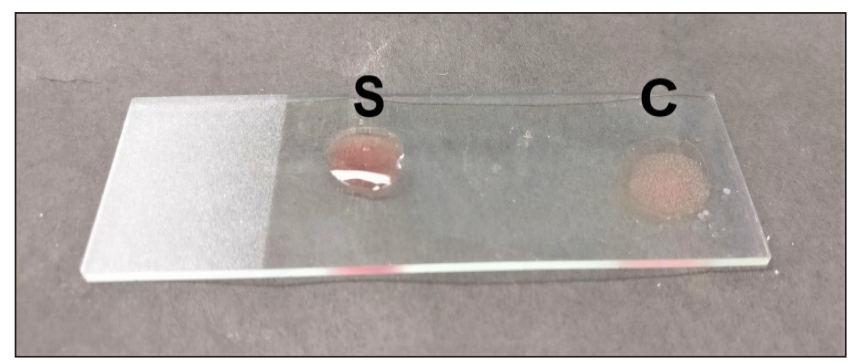

Fig. 8: Coagulase test reaction of isolated Endophytic bacteria from leaves of Tamarindus indica

\section{RESULTS AND DISCUSSION}

The microscopic examination of endophytic bacterial isolates had shown that all endophytic bacterial isolates from Tamarindus indica were gram positive rods and only one type of bacteria was present. The biochemical characterization of endophytic bacterial isolates showed positive reaction to catalase, Vogasproskaur's (VP) Orthro-Nitrophenyl- $\beta$-galactoside (ONPG), urease and negative reaction to coagulase, arginine utilization test. The endophytic bacteria isolates were evaluated for the presence of active hydrolytic Khanam and Chandra (2015) had isolated endophytic bacteria from Beta vulgaris having morphological characteristics of umbonate elevation, entire margin and red coloured colonies. Soman (2018) had isolated endophytic bacteria from leaves of Acacia nilotica and the colonies were circular in shape with raised elevation while endophytic bacteria isolated from the leaves of Acacia catechu were irregular in shape, flat elevation on petri plate, entire colony margins, and the surface of the growth was smooth, opaque and white in colour. The endophytic bacteria isolated from the leaves of Acacia auriculiformis were irregular in shape, flat elevation on petri plate, undulated colony margin; the surface of the 
S

Sawarkar et al.

Table 3: Gram's staining of Endophytic bacterial isolated from leaves Tamarindus indica

\begin{tabular}{lllll}
\hline Sl. No. & Isolate No. & Gram's staining & Shape & Types of bacteria \\
\hline 1 & JN-1a & Positive & Rod & 01 \\
2 & JN-1b & Positive & Rod & 01 \\
3 & JN-1c & Positive & Rod & 01 \\
4 & JN-1d & Positive & Rod & 01 \\
5 & JN-1e & Positive & Rod & 01 \\
6 & TF-2a & Positive & Rod & 01 \\
7 & TF-2b & Positive & Rod & 01 \\
8 & TF-2c & Positive & Rod & 01 \\
9 & TF-2d & Positive & Rod & 01 \\
10 & TF-2e & Positive & Rod & 01 \\
11 & SF-3a & Positive & Rod & 01 \\
12 & SF-3b & Positive & Rod & 01 \\
13 & SF-3c & Positive & Rod & 01 \\
14 & SF-3d & Positive & Rod & 01 \\
15 & SF-3e & Positive & Rod & 01 \\
\hline
\end{tabular}

Table 4: Biochemical tests of endophytic bacteria

\begin{tabular}{|c|c|c|c|c|c|c|c|}
\hline SI. No. & Isolate No. & Catalase test & Coagulase test & VP test & ONPG test & Urease test & $\begin{array}{l}\text { Arginine } \\
\text { utilization test }\end{array}$ \\
\hline 1 & $\mathrm{JN}-1 \mathrm{a}$ & Positive & Negative & Positive & Positive & Positive & Negative \\
\hline 2 & $\mathrm{JN}-1 \mathrm{~b}$ & Positive & Negative & Positive & Positive & Positive & Negative \\
\hline 3 & $\mathrm{JN}-1 \mathrm{c}$ & Positive & Negative & Positive & Positive & Positive & Negative \\
\hline 4 & $\mathrm{JN}-1 \mathrm{~d}$ & Positive & Negative & Positive & Positive & Positive & Negative \\
\hline 5 & $\mathrm{JN}-1 \mathrm{e}$ & Positive & Negative & Positive & Positive & Positive & Negative \\
\hline 6 & $\mathrm{TF}-2 \mathrm{a}$ & Positive & Negative & Positive & Positive & Positive & Negative \\
\hline 7 & $\mathrm{TF}-2 \mathrm{~b}$ & Positive & Negative & Positive & Positive & Positive & Negative \\
\hline 8 & $\mathrm{TF}-2 \mathrm{c}$ & Positive & Negative & Positive & Positive & Positive & Negative \\
\hline 9 & $\mathrm{TF}-2 \mathrm{~d}$ & Positive & Negative & Positive & Positive & Positive & Negative \\
\hline 10 & TF-2e & Positive & Negative & Positive & Positive & Positive & Negative \\
\hline 11 & SF-3a & Positive & Negative & Positive & Positive & Positive & Negative \\
\hline 12 & SF-3b & Positive & Negative & Positive & Positive & Positive & Negative \\
\hline 13 & SF-3c & Positive & Negative & Positive & Positive & Positive & Negative \\
\hline 14 & SF-3d & Positive & Negative & Positive & Positive & Positive & Negative \\
\hline 15 & SF-3e & Positive & Negative & Positive & Positive & Positive & Negative \\
\hline
\end{tabular}

growth was equally smooth and dull, opaque and white in colour. Baghat et al. (2014), who found that the 90 per cent of isolated endophytic bacteria from Capparis sinaica were gram positive in nature. Prasad and Dagar (2014) had isolated endophytes from Avacado and Black grapes which were gram positive rods. The coagulase negative reaction suggests that isolates were nonpathogenic in nature. The present findings are very near to the work of Khanam and Chandra (2015).

\section{CONCLUSION}

All the endophytic bacterial isolates from leaves of Tamarindus indica were having different growth characteristic in King's B media, BHI broth and on Sheep blood agar. The microscopic examination of endophytic bacterial isolates had shown that all endophytic bacterial isolates from Tamarindus indica were gram positive rods and only one type of bacteria was present. The biochemical characterization of endophytic bacterial isolates showed 
positive reaction to catalase, Vogasproskaur's (VP) Orthro-Nitrophenyl- $\beta$-galactoside (ONPG), urease and negative reaction to coagulase, arginine utilization test. The endophytic bacteria isolates were evaluated for the presence of active hydrolytic.

\section{ACKNOWLEDGEMENTS}

Our deepest gratitude to Hon'ble Dean, College of Veterinary Science and Animal Husbandry, NDVSU, Jabalpur (M.P), INDIA for providing the facilities to conduct this study.

\section{REFERENCES}

Beneduzi, A., Moreira, F., Costa, P.B., Vargas, L.K., Lisboa, B.B., Favreto, R., Baldani, J.I. and Passaglia, L.M.P. 2013. Diversity and plant growth promoting evaluation abilities of bacteria isolated from Sugarcane cultivated in the south of Brazil. Appl. Soil Ecol., 4: 94-104.

Compant, S., Clement, C. and Sessitsch, A. 2010. Colonization of plant growth-promoting bacteria in the rhizo and endosphere of plants: Importance, mechanisms involved and future prospects. Soil. Biol. Biochem., 42: 669-678.

Khanam, B. and Chandra, R.2015. Isolation and identification of endophytic bacteria producing bright red pigment from the dye yielding plant Beta vulgaris. Int J. Pharm. Sci., 7(5): 220-224.
Mahajan, S., Bakshi, S., Bansal, D. and Bhasin, P. 2014. Isolation and characterization of endophytes. Int. J. Sci. Res., 1: 29-33.

Mishra, C. 1997. Cloning and expressing of two chitin deacetylase gene of Sacharomyces cerevisiae yeast., Soc. Appl. Microb., 13(4): 327-36.

Prasad, M.P. and Dagar, S. 2014. Identification and characterization of endophytic bacteria from fruits like Avacado and Black grapes. Int. J. Curr. Microbiol. Appl. Sci., 3(8): 937-947.

Rao, P.S., Murti, S.S. and Neasmani, K. and Venkaih, K. 1999. Albinism in Ariocorpus integrifolia a case study. Indian Forester, 125(11): 1095-1098.

Rekha, M., Gupta, P., Kale, R., Madhuri, L., Rathi, N. and Jadhav, P. 2015. Isolation, characterization and identification of endophytic bacteria by $16 \mathrm{~S}$ rRNA partial sequencing technique from roots and leaves of Prosopis cineraria plant. Asian J. Plant Sci., 5(6): 36-43.

Soman, S. 2018. Studies on antibacterial activity of endophytic bacteria isolated from Acacia nilotica, Acacia catechu and Acacia auriculiformis. M.V.Sc. Thesis (Veterinary Pharmacology and Toxicology). Nanaji Deshmukh Veterinary Science University, Jabalpur.

Sturz, A.V. and Nowak, J. 2000. Endophytic communities of rhizobacteria and the strategies required to create yield enhancing association with crops, Appl. Soil Ecol., 15: 182190. 
